Published in final edited form as:

Biochem Biophys Res Commun. 2016 February 19; 470(4): 783-791. doi:10.1016/j.bbrc.2016.01.064.

\title{
Tribbles 3 Inhibits Brown Adipocyte Differentiation and Function by Suppressing Insulin Signaling
}

\author{
Ha-Won Jeong ${ }^{1}$, Ran Hee Choi ${ }^{1}$, Jamie L. McClellan ${ }^{1}$, Gerardo G. Piroli ${ }^{2}$, Norma Frizzell ${ }^{2}$, \\ Yu-Hua Tseng ${ }^{3}$, Laurie J. Goodyear ${ }^{3}$, and Ho-Jin Koh ${ }^{1,4}$ \\ ${ }^{1}$ Division of Applied Physiology, Department of Exercise Science, University of South Carolina, \\ Columbia, SC 29208 \\ ${ }^{2}$ Department of Pharmacology, Physiology \& Neuroscience, University of South Carolina School \\ of Medicine, Columbia, SC 29208 \\ ${ }^{3}$ Research Division, Joslin Diabetes Center and Department of Medicine, Harvard Medical \\ School, Boston, MA 02215
}

\begin{abstract}
Recent studies have demonstrated that adult humans have substantial amounts of functioning brown adipose tissue (BAT). Since BAT has been implicated as an anti-obese and anti-diabetic tissue, it is important to understand the signaling molecules that regulate BAT function. There has been a link between insulin signaling and BAT metabolism as deletion or pharmaceutical inhibition of insulin signaling impairs BAT differentiation and function. Tribbles 3 (TRB3) is a pseudo kinase that has been shown to regulate metabolism and insulin signaling in multiple tissues but the role of TRB3 in BAT has not been studied. In this study, we found that TRB3 expression was present in BAT and overexpression of TRB3 in brown preadipocytes impaired differentiation and decreased expression of BAT markers. Furthermore, TRB3 overexpression resulted in significantly lower oxygen consumption rates for basal and proton leakage, indicating decreased BAT activity. Based on previous studies showing that deletion or pharmaceutical inhibition of insulin signaling impairs BAT differentiation and function, we assessed insulin signaling in brown preadipocytes and BAT in vivo. Overexpression of TRB 3 in cells impaired insulin-stimulated IRS1 and Akt phosphorylation, whereas TRB3KO mice displayed improved IRS1 and Akt phosphorylation. Finally, deletion of IRS1 abolished the function of TRB3 to regulate BAT differentiation and metabolism. These data demonstrate that TRB3 inhibits insulin signaling in BAT, resulting in impaired differentiation and function.
\end{abstract}

\section{Keywords}

Brown Adipose Tissue; UCP1; Insulin signaling

\footnotetext{
${ }^{4}$ Address correspondence to: Ho-Jin Koh, Department of Exercise Science, University of South Carolina, 921 Assembly St., Columbia, South Carolina 29208, USA. Phone: +1-803-777-1462; Fax: +1-803-777-0558; Kohh@ mailbox.sc.edu.

Publisher's Disclaimer: This is a PDF file of an unedited manuscript that has been accepted for publication. As a service to our customers we are providing this early version of the manuscript. The manuscript will undergo copyediting, typesetting, and review of the resulting proof before it is published in its final citable form. Please note that during the production process errors may be discovered which could affect the content, and all legal disclaimers that apply to the journal pertain.
} 


\section{INTRODUCTION}

It has long been thought that stimulating adaptive thermogenesis might prevent or treat obesity and diabetes [1]. Expanding the activity of brown fat in mice through genetic manipulation, drugs or transplantation suppresses metabolic disease and improves insulin sensitivity [2-4]. Mice with increased activity of BAT resist weight gain and display improvements in systemic metabolism [2, 5]. Consistently, Uncoupling protein 1 (UCP1)deficient mice and transgenic mice with toxigene-mediated reduction of BAT gain more weight than controls and develop insulin resistance at thermoneutral $\left(28-30^{\circ} \mathrm{C}\right)$ conditions $[6,7]$. Despite its potential physiological importance, study of this concept has been neglected due to the belief that BAT is limited to rodents and human infants. However, recent studies from different groups demonstrated that functional BAT is present in adults [8-10]. The identification of functional BAT in adults has evoked widespread interest in the basic and clinical research related to obesity, diabetes, and metabolic diseases.

Active BAT produces heat by the inducible thermogenesis system to maintain body temperature in cold exposure through activation of UCP1, a protein that facilitates proton leak into the mitochondrial matrix, bypassing ATP synthase. UCP1 therefore leads to waste energy and acts against excess energy accumulation, resulting in the prevention or treatment of obesity and metabolic diseases. Given the recognition of BAT in humans, it is important to understand the regulation mechanism for UCP1 expression and BAT function, but the mechanism has never been elucidated.

TRB3, a mammalian homolog of Drosophila tribbles, is a pseudokinase and therefore contains a kinase domain without enzymatic activity [11]. TRB3 is expressed in various tissues, including liver, adipose tissue, heart, and skeletal muscle [12-15]. In the liver, TRB3 binds and inhibits Akt activity, leading to impaired insulin signaling [12]. Overexpression of TRB3 in mouse liver results in decreased glycogen content, increased hepatic glucose output and blood glucose concentrations, and impaired glucose tolerance [12], whereas disruption of TRB3 in mouse liver by RNAi improves glucose tolerance [12]. In pancreatic $\beta$ cells, overexpression of TRB3 in mice inhibits glucose-stimulated insulin secretion and impairs glucose homeostasis [16]. However, studies performed in adipose tissue suggest TRB3 has a very different role, functioning in the regulation of fatty acid oxidation through ubiquitination of Acetyl-CoA Carboxylase [13]. Mice overexpressing TRB3 in adipose tissue are protected from diet-induced obesity due to enhanced fatty acid oxidation [13]. The role of TRB3 in BAT has not been studied and therefore remains to be elucidated.

In the current study we tested the hypothesis that TRB3 inhibits BAT differentiation and its function. We found that TRB3 expression is present in mouse BAT. Overexpression of TRB3 in brown preadipocytes inhibits differentiation, UCP1 expression and insulin signaling, which are associated with decreased oxygen consumption rates for basal and proton leakage. In addition, TRB3 knockout mice display improved insulin signaling in BAT. These data demonstrate that TRB3 inhibits BAT differentiation and metabolism presumably via insulin signaling. 


\section{MATERIALS AND METHODS}

\section{Animals}

Protocols for animal use and experimental procedures were conducted in accordance with NIH guidelines and approved by the Institutional Animal Care and Use Committee of the Joslin Diabetes Center and University of South Carolina. C57BL/6 wild type mice from Charles River, or whole body TRB3 knockout mice [17] were maintained in a pathogen-free animal facility under standard 12-hour light/12-hour dark cycle, and unless indicated, were maintained on a chow diet (20\% of calorie from fat; Lab Diet 5020). Mice were studied at 8-12 weeks of age, as specified in figure legends.

\section{Cell culture}

Immotalized brown preadipocytes were maintained and differentiated as described [18-20]. Briefly, brown preadipocytes were grown to confluence in differentiation media (DMEM containing $20 \mathrm{nM}$ Insulin, $1 \mathrm{nM}$ T3 and 10\% FBS) and then media were changed into induction media (differentiaton media, $125 \mathrm{mM}$ Indomethacin, $2 \mathrm{mg} / \mathrm{ml}$ dexamethasone and 250 mM IBMX; defined as Day 0). After $48 \mathrm{hr}$ incubation (Day 2), cell media were switched back to differentiation media and renewed with fresh differentiation media every second day afterward.

\section{Measurements of oxygen consumption}

Cellular metabolic rates were measured using a XF24 Analyzer (Seahorse Bioscience). Brown preadipocytes were seeded (30,000 cells/well) into gelatin-coated XF24 V7 cell culture plates (Seahorse Bioscience) and cultured overnight at $37^{\circ} \mathrm{C}$ with $5 \% \mathrm{CO}_{2}$. The next day, cells were induced to differentiate to brown adipocytes for 5 days. At the end of differentiation, the media were replaced with pre-warmed XF24 assay medium (DMEM, 1 mM Glutamax-1, $2 \mathrm{mM}$ pyruvate, $141 \mathrm{mM} \mathrm{NaCl}$ and $25 \mathrm{mM}$ glucose) for $1 \mathrm{hr}$. $\mathrm{O}_{2}$ tension immediately around the cells was measured by optical fluorescent biosensors embedded in a sterile disposable cartridge placed into the wells of the microplate during the assay. The measurement was done at baseline and following injection of oligomycin $(2 \mu \mathrm{M}$; Calbiochem; ATP turnover), carbonyl cyanide p-trifluoromethoxy phenylhydrazone (FCCP, $1 \mu \mathrm{M}$; Sigma; maximum respiratory capacity) and rotenone ( $1 \mu \mathrm{M}$; sigma; nonmitochondrial respiration). Oxygen consumption rate (OCR) was calculated by plotting the $\mathrm{O}_{2}$ tension of the medium in the microenvironment above the cells as a function of time $\left(\right.$ pmoles $\min ^{-1}$ ). Proton leak was also calculated by subtracting the ATP turnover and the non-mitochondrial respiration components of basal respiration. Respiration results were normalized to the DNA content measured spectrofluorometrically.

\section{RNA isolation and Real-time PCR analysis}

Total RNA was extracted from brown preadipocytes or mouse brown adipose tissue using TRIzol (Life Technologies). First strand cDNA was synthesized using High Capacity cDNA kit (Life Technologies). Primer sequences for the Real-time PCR were as follows: TBP, F 5'-ACCCTTCACCAATGACTCCTATG-3', R 5'-TGACTGCAGCAAATCGCTTGG-3'; TRB3, F 5'-TCTCCTCCGCAAGGAACCT-3', R 5'-TCTCAACCAGGGATGCAAGAG-3'; 
PRDM16, F 5'-GACATTCCAATCCCACCAGA-3', R 5'-

CACCTCTGTATCCGTCAGCA-3'; UCP1, F 5'-ACTGCCACACCTCCAGTCATT-3', R 5'-CTTTGCCTCACTCAGGATTGG-3'; PPAR $\gamma$, F 5'-TCAGCTCTGTGGACCTCTCC-3', R 5'-ACCCTTGCATCCTTCACAAG-3'; CIDEA, F 5'-

TGCTCTTCTGTATCGCCCAGT-3', R 5'-GCCGTGTTAAGGAATCTGCTG-3'. Relative mRNA levels were calculated with the PCR product for each primer set normalized to TBP RNA.

\section{Western blot analysis and antibodies}

Tissues and cells were rapidly processed in lysis buffer [21, 22]. Western blot analyses were used to assess protein and phosphorylation levels of various molecules. Primary antibodies purchased from commercial sources included a-tubulin, UCP1 (Santa Cruz); IRS1 (Upstate); IRS-1-Tyr ${ }^{612}$ (Biosource); and p-Akt-Ser ${ }^{473}$, Akt, (Cell Signaling). Secondary antibodies used were horseradish peroxidase (HRP)-conjugated anti-rabbit (Amersham), HRP-conjugated anti-mouse (Upstate), and HRP-conjugated anti-goat (Promega). All the indicated antibodies were used at the dilutions suggested by the manufacturer. Antibody to TRB3 was a gift from Dr. Montminy [12]. Blots were developed using ECL reagents (Amersham Pharmacia), and bands were visualized and quantified using ImageJ (NIH).

\section{Statistical analysis}

Data are means \pm S.E.M. All data were compared using Student's t-test, one-way ANOVA, or two-way ANOVA. The differences between groups were considered significant when $p<$ 0.05 .

\section{RESULTS}

\section{Overexpression of TRB3 inhibits brown adipose differentiation and function}

TRB 3 is expressed in multiple tissues, including liver, adipose tissue, pancreatic $\beta$ cells and skeletal muscle [12, 13, 16, 22], and here we first determined the TRB3 expression in brown adipose tissue (BAT). TRB3 expression was high in liver and pancreas and lower in white adipose tissue (WAT) (Fig. 1a). TRB3 was notably expressed in BAT (Fig. 1a).

We next determined if overexpression of TRB3 would regulate BAT differentiation and/or function. Since TRB3 has been shown to inhibit differentiation of myoblast and preadipose cells, C2C12 and 3T3-L1 [23, 24], we hypothesized that TRB3 regulates BAT differentiation and function. To this end, we studied brown preadipocytes that were established in earlier studies [18, 19], and first analyzed the TRB3 expression during differentiation. TRB3 mRNA was increased by 6.8 -fold compared to initial levels as the preadipocytes underwent 8 days of differentiation (Fig. 1b). This change occurred in parallel with changes in established brown adipose tissue markers, including PRDM16, Cell death activator (CIDEA), Peroxisome proliferator-activated receptor $\gamma$ (PPAR $\gamma$ ) and UCP1 (Fig. 1 $\mathrm{f}-\mathrm{i}$ ). To determine the role of TRB 3 on brown adipose differentiation, we stably expressed TRB3 in brown preadipocytes using retrovirus, which resulted in 42-fold overexpression of TRB3 compare to control cells (Fig. 1c), and then assessed the differentiation to brown adipocyte by Oli-Red $\mathrm{O}$ staining, a specific dye for triglycerides and lipids. Overexpression 
of TRB3 showed a marked defect in differentiation compared to control cells (Fig. 1d and e). The decreased differentiation was associated with suppression of gene expression involved in brown adipocyte differentiation, including PRDM16, CIDEA and PPAR $\gamma$ (Fig. 1 f-h). Importantly, overexpression of TRB3 inhibited UCP1 mRNA and protein expression (Fig. 1i and j). These data suggest that overexpression of TRB3 negatively regulates brown adipocyte differentiation.

\section{TRB3 modulates cellular bioenergetics in brown adipose tissue}

One of the characteristics of BAT is high uncoupling and oxygen consumption rates (OCR). Consequently, measuring metabolic rate has been used to assess BAT activity [25-28]. Since TRB3 appears to regulate BAT differentiation and insulin signaling, we hypothesized that TRB3 regulates cellular bioenergetics in BAT. To determine the effects of TRB3 on metabolic rate in BAT, wild type and TRB3 overexpressing brown preadipocytes were differentiated for 5 days to measure OCRs for various components using the Seahorse XF24 analyzer (Fig. 2a). Overexpression of TRB3 displayed significantly lower basal OCR compared to control cells (Fig. 2a and b). OCR for proton leak and ATP turnover was then measured following administration of oligomycin (an inhibitor of ATP synthase) and subsequently rotenone (an inhibitor of mitochondrial respiratory chain complex I). TRB3 overexpression exhibited lower proton leak associated OCR compared to controls by $51 \%$ (Fig. 2c), whereas no change in ATP turnover (Fig. 2d). Maximal respiration tended to decrease with TRB3 overexpression, although the difference was not statistically significant (Fig. 2e). These data demonstrate that TRB3 impairs cellular metabolism in brown preadipocytes and therefore lower activity.

\section{TRB3 regulates insulin signaling in BAT}

Since TRB3 has been shown to inhibit insulin signaling in multiple tissues [12, 22] and deletion or pharmaceutical inhibition of insulin signaling impairs BAT differentiation and function [18-20], we hypothesized that TRB3 regulates BAT function via inhibition of insulin signaling. Therefore, we determined the effects of TRB3 on insulin signaling in BAT. Compared to control cells, overexpression of TRB3 in brown preadipocyte cells resulted in a significant decrease in insulin-stimulated IRS1 Tyr $^{612}$ phosphorylation (Fig. 3a and b), an upstream regulator of PI3 kinase activity [29]. Consistently, insulin-stimulated Akt Ser ${ }^{473}$ was also significantly decreased with overexpression of TRB3 (Fig. 3a and c). Expression of IRS1 and Akt was not different between groups (Fig. 3a). We next studied TRB3 knockout (TRB3KO) mice if deletion of TRB3 would improve insulin signaling in BAT. The TRB3KO mice have been generated and studied in previous studies [17, 22]. Wild type or TRB3KO mice were injected with saline or insulin (1U/kg; i.p.) and BAT was dissected to determine insulin signaling. Insulin-stimulated IRS1 Tyr ${ }^{612}$ and Akt Ser ${ }^{473}$ phosphorylation was enhanced in BAT from TRB3KO mice compared to wild type mice (Fig. $3 \mathrm{~d}-\mathrm{f}$ ). These data demonstrate that TRB3 regulates insulin signaling in BAT.

\section{Overexpression of TRB3 does not alter differentiation in IRS1KO brown preadipocytes}

Given that TRB3 regulated insulin signaling in BAT, we next determined if IRS1/Akt signaling is required for the TRB3 regulation of BAT differentiation and function. To this end, we studied brown preadipocytes from IRS1 knokcout mice. IRS1KO brown 
preadipocytes have been shown to inhibit differentiation [18-20]. Consistent with previous study [19], TRB3 expression was higher in IRS1KO cells compared to wild type cells by 2.9-fold (Fig. 4a). We overexpressed TRB3 in IRS1KO cells and differentiated the cells for 8 days. Overexpression of TRB 3 in IRS1KO cells did not alter differentiation by measuring Oil-Red O staining (Fig. 4b). We differentiated the cells further up to 12 days and we could not find any difference in Oil-Red O staining between two groups (data not shown). mRNA expression of PRDM16 and UCP1 was not different between two groups, with a significant decrease in UCP1 expression only at 8 days of differentiation in TRB3 overexpressing cells (Fig. 4c). These data suggest that IRS1/Akt signaling is important for the function of TRB3 to regulate BAT differentiation and metabolism.

\section{DISCUSSION}

It is now well established that igniting thermogenesis has attractive perspectives for health [1]. Not only would it enable us to prevent obesity in response to an excess of food, but it would also counteract obesity-related comorbidities, including type 2 diabetes. Therefore, it is important to understand the molecular mechanisms leading to the impairments in BAT metabolism and activity. In the current study we tested the hypothesis that TRB3 plays a role in the regulation of BAT metabolism and function. The current results support this hypothesis as indicated by: 1) overexpression of TRB3 in brown preadipocytes impaired differentiation, insulin signaling and oxygen consumption rate; 2) knockout of TRB3 in mice significantly improved insulin signaling in BAT; and 3) effects of TRB3 on BAT differentiation was reduced in the brown preadipocytes from IRS1 knockout mice.

The role of TRB3 in BAT has not been studied and therefore remains to be elucidated. Qi et al. have generated a transgenic mouse overexpressing TRB3 in white and brown adipose tissue under control of aP2 promoter [13]. The transgenic mice are protected from dietinduced obesity and display enhanced fatty acid oxidation and increased oxygen consumption [13]. Due to the overexpression of TRB3 in both white and brown adipose tissue, it is difficult to differentiate the overexpression effects of TRB3 in white and brown adipose tissue and therefore, the role of this protein in BAT needs to be determined. They also did not study the role of TRB3 on BAT differentiation in the study.

Okamoto et al. reported generation of whole body TRB3 knockout mice [17]. Given the function of TRB3 in BAT, we would expect to see a change in energy metabolism, especially oxygen consumption. However, the TRB3KO mice showed no difference in basal metabolic rates and resting oxygen consumption [17]. The lack of effect may be due to the different functions of TRB3 in various tissues, thereby a metabolic effect from one tissue in TRB3KO mice would be diminished by a different effect from another tissue. TRB3 has been shown to inhibit insulin signaling in liver and skeletal muscle $[12,15,22]$ but role of the protein in white adipocytes is to promote fatty acid oxidation. Thus, the beneficial effects of a reduction in BAT TRB3 expression on energy metabolism may be masked by the detrimental effects of a reduction in adipocyte TRB3 expression. Whether BAT TRB3 affects whole body metabolism will be important area of future investigation and the study is ongoing in our laboratory. 
A role for TRB3 in inhibiting brown preadipocytes differentiation is reasonable given recent indications that TRB3 plays an important role in adipocytes and myoblast differentiation $[23,24,30]$. TRB3 inhibits adipocyte differentiation through inhibition of transcription factors, PPAR $\gamma$ [30] or C/EBP $\beta$ [24]. In current study we found that TRB3 overexpression in brown preadipocytes inhibits cellular differentiation and BAT metabolism. The inhibition of BAT differentiation by TRB3 appears to be the result of insulin signaling inhibition. Overexpression of TRB3 in brown preadipocytes inhibits insulin signaling and the effects of TRB3 on the regulation of BAT differentiation and metabolism was significantly diminished in IRS1KO cells. Previous studies demonstrated that inhibition of insulin signaling impairs BAT differentiation and function [18-20, 31]. Knockout of insulin receptor or IRS1 in mice or brown preadipocytes inhibits cellular differentiation. Furthermore, treatment of brown preadipocytes with PI 3-kinase inhibitor LY294002 significantly decreases differentiation [20]. Thus, the available data suggest that TRB3 regulates BAT differentiation and activity via regulation of insulin signaling.

In summary, TRB3 is an important regulator for BAT differentiation and metabolism. TRB3 inhibits insulin signaling in BAT, which in turn blocking BAT differentiation and its activity. Knockdown of TRB3 significantly improves insulin signaling in mouse BAT. Our data also suggest that inhibition of TRB3 expression in BAT may be a new therapeutic target for effectively managing BAT activity and function.

\section{Supplementary Material}

Refer to Web version on PubMed Central for supplementary material.

\section{Acknowledgments}

The authors thank Dr. M. Montminy (Salk Institute) for providing TRB3 antibody, Regeneron for TRB3KO mice, and Dr. M. Shim (University of South Carolina) for technical help. This work was supported by NIH grants to H.J.K. (5P20GM103641-03 and 1P20GM109091-01) and departmental start-up grant to H.J.K.

\section{REFERENCES}

1. Lowell BB, Spiegelman BM. Towards a molecular understanding of adaptive thermogenesis. Nature. 2000; 404:652-660. [PubMed: 10766252]

2. Cederberg A, Gronning LM, Ahren B, Tasken K, Carlsson P, Enerback S. FOXC2 is a winged helix gene that counteracts obesity, hypertriglyceridemia, and diet-induced insulin resistance. Cell. 2001; 106:563-573. [PubMed: 11551504]

3. Kopecky J, Clarke G, Enerback S, Spiegelman B, Kozak LP. Expression of the mitochondrial uncoupling protein gene from the aP2 gene promoter prevents genetic obesity. J Clin Invest. 1995; 96:2914-2923. [PubMed: 8675663]

4. Stanford KI, Middelbeek RJ, Townsend KL, An D, Nygaard EB, Hitchcox KM, Markan KR, Nakano K, Hirshman MF, Tseng YH, Goodyear LJ. Brown adipose tissue regulates glucose homeostasis and insulin sensitivity. J Clin Invest. 2013; 123:215-223. [PubMed: 23221344]

5. Bordicchia M, Liu D, Amri EZ, Ailhaud G, Dessi-Fulgheri P, Zhang C, Takahashi N, Sarzani R, Collins S. Cardiac natriuretic peptides act via p38 MAPK to induce the brown fat thermogenic program in mouse and human adipocytes. J Clin Invest. 2012; 122:1022-1036. [PubMed: 22307324] 
6. Feldmann HM, Golozoubova V, Cannon B, Nedergaard J. UCP1 ablation induces obesity and abolishes diet-induced thermogenesis in mice exempt from thermal stress by living at thermoneutrality. Cell Metab. 2009; 9:203-209. [PubMed: 19187776]

7. Hamann A, Flier JS, Lowell BB. Decreased brown fat markedly enhances susceptibility to dietinduced obesity, diabetes, and hyperlipidemia. Endocrinology. 1996; 137:21-29. [PubMed: 8536614]

8. Cypess AM, Lehman S, Williams G, Tal I, Rodman D, Goldfine AB, Kuo FC, Palmer EL, Tseng YH, Doria A, Kolodny GM, Kahn CR. Identification and importance of brown adipose tissue in adult humans. N Engl J Med. 2009; 360:1509-1517. [PubMed: 19357406]

9. van Marken Lichtenbelt WD, Vanhommerig JW, Smulders NM, Drossaerts JM, Kemerink GJ, Bouvy ND, Schrauwen P, Teule GJ. Cold-activated brown adipose tissue in healthy men. N Engl J Med. 2009; 360:1500-1508. [PubMed: 19357405]

10. Virtanen KA, Lidell ME, Orava J, Heglind M, Westergren R, Niemi T, Taittonen M, Laine J, Savisto NJ, Enerback S, Nuutila P. Functional brown adipose tissue in healthy adults. N Engl J Med. 2009; 360:1518-1525. [PubMed: 19357407]

11. Wu M, Xu LG, Zhai Z, Shu HB. SINK is a p65-interacting negative regulator of NF-kappaBdependent transcription. J. Biol. Chem. 2003; 278:27072-27079. [PubMed: 12736262]

12. Du K, Herzig S, Kulkarni RN, Montminy M. TRB3: a tribbles homolog that inhibits Akt/PKB activation by insulin in liver. Science. 2003; 300:1574-1577. [PubMed: 12791994]

13. Qi L, Heredia JE, Altarejos JY, Screaton R, Goebel N, Niessen S, Macleod IX, Liew CW, Kulkarni RN, Bain J, Newgard C, Nelson M, Evans RM, Yates J, Montminy M. TRB3 links the E3 ubiquitin ligase COP1 to lipid metabolism. Science. 2006; 312:1763-1766. [PubMed: 16794074]

14. Avery J, Etzion S, DeBosch BJ, Jin X, Lupu TS, Beitinjaneh B, Grand J, Kovacs A, Sambandam N, Muslin AJ. TRB3 function in cardiac endoplasmic reticulum stress. Circ. Res. 2010; 106:15161523. [PubMed: 20360254]

15. Koh HJ, Arnolds DE, Fujii N, Tran TT, Rogers MJ, Jessen N, Li Y, Liew CW, Ho RC, Hirshman MF, Kulkarni RN, Kahn CR, Goodyear LJ. Skeletal muscle-selective knockout of LKB1 increases insulin sensitivity, improves glucose homeostasis, and decreases TRB3. Mol Cell Biol. 2006; 26:8217-8227. [PubMed: 16966378]

16. Liew CW, Bochenski J, Kawamori D, Hu J, Leech CA, Wanic K, Malecki M, Warram JH, Qi L, Krolewski AS, Kulkarni RN. The pseudokinase tribbles homolog 3 interacts with ATF4 to negatively regulate insulin exocytosis in human and mouse beta cells. J Clin Invest. 2010; 120:2876-2888. [PubMed: 20592469]

17. Okamoto H, Latres E, Liu R, Thabet K, Murphy A, Valenzeula D, Yancopoulos GD, Stitt TN, Glass DJ, Sleeman MW. Genetic deletion of Trb3, the mammalian Drosophila tribbles homolog, displays normal hepatic insulin signaling and glucose homeostasis. Diabetes. 2007; 56:1350-1356. [PubMed: 17303803]

18. Tseng YH, Kriauciunas KM, Kokkotou E, Kahn CR. Differential roles of insulin receptor substrates in brown adipocyte differentiation. Molecular and cellular biology. 2004; 24:19181929. [PubMed: 14966273]

19. Tseng YH, Butte AJ, Kokkotou E, Yechoor VK, Taniguchi CM, Kriauciunas KM, Cypess AM, Niinobe M, Yoshikawa K, Patti ME, Kahn CR. Prediction of preadipocyte differentiation by gene expression reveals role of insulin receptor substrates and necdin. Nat. Cell Biol. 2005; 7:601-611. [PubMed: 15895078]

20. Fasshauer M, Klein J, Kriauciunas KM, Ueki K, Benito M, Kahn CR. Essential role of insulin receptor substrate 1 in differentiation of brown adipocytes. Molecular and cellular biology. 2001; 21:319-329. [PubMed: 11113206]

21. Fujii N, Boppart MD, Dufresne SD, Crowley PF, Jozsi AC, Sakamoto K, Yu H, Aschenbach WG, Kim S, Miyazaki H, Rui L, White MF, Hirshman MF, Goodyear LJ. Overexpression or ablation of JNK in skeletal muscle has no effect on glycogen synthase activity. Am J Physiol Cell Physiol. 2004; 287:C200-C208. [PubMed: 15013949]

22. Koh HJ, Toyoda T, Didesch MM, Lee MY, Sleeman MW, Kulkarni RN, Musi N, Hirshman MF, Goodyear LJ. Tribbles 3 mediates endoplasmic reticulum stress-induced insulin resistance in skeletal muscle. Nature communications. 2013; 4:1871. 
23. Kato S, Du K. TRB3 modulates C2C12 differentiation by interfering with Akt activation. Biochem Biophys. Res Commun. 2007; 353:933-938. [PubMed: 17207467]

24. Bezy O, Vernochet C, Gesta S, Farmer SR, Kahn CR. TRB3 blocks adipocyte differentiation through the inhibition of C/EBPbeta transcriptional activity. Mol Cell Biol. 2007; 27:6818-6831. [PubMed: 17646392]

25. Plaisier CL, Bennett BJ, He A, Guan B, Lusis AJ, Reue K, Vergnes L. Zbtb16 has a role in brown adipocyte bioenergetics. Nutrition \& diabetes. 2012; 2:e46. [PubMed: 23446662]

26. Sun L, Xie H, Mori MA, Alexander R, Yuan B, Hattangadi SM, Liu Q, Kahn CR, Lodish HF. Mir193b-365 is essential for brown fat differentiation. Nature cell biology. 2011; 13:958-965. [PubMed: 21743466]

27. Sharma A, Huard C, Vernochet C, Ziemek D, Knowlton KM, Tyminski E, Paradis T, Zhang Y, Jones JE, von Schack D, Brown CT, Milos PM, Coyle AJ, Tremblay F, Martinez RV. Brown fat determination and development from muscle precursor cells by novel action of bone morphogenetic protein 6. PloS one. 2014; 9:e92608. [PubMed: 24658703]

28. Vijgen GH, Sparks LM, Bouvy ND, Schaart G, Hoeks J, van Marken Lichtenbelt WD, Schrauwen $P$. Increased oxygen consumption in human adipose tissue from the "brown adipose tissue" region. J Clin Endocrinol Metab. 2013; 98:E1230-E1234. [PubMed: 23783102]

29. Esposito DL, Li Y, Cama A, Quon MJ. Tyr(612) and tyr(632) in human insulin receptor substrate-1 are important for full activation of insulin-stimulated phosphatidylinositol 3-kinase activity and translocation of glut4 in adipose cells. Endocrinology. 2001; 142:2833-2840. [PubMed: 11416002]

30. Takahashi Y, Ohoka N, Hayashi H, Sato R. TRB3 suppresses adipocyte differentiation by negatively regulating PPARgamma transcriptional activity. Journal of lipid research. 2008; 49:880-892. [PubMed: 18187772]

31. Entingh AJ, Taniguchi CM, Kahn CR. Bi-directional regulation of brown fat adipogenesis by the insulin receptor. J Biol Chem. 2003; 278:33377-33383. [PubMed: 12807888] 


\section{HIGHLIGHTS}

- $\quad$ TRB3 is expressed in brown adipose tissue and its expression is increased during differentiation.

- Overexpression of TRB3 inhibits differentiation and its activity.

- Overexpression of TRB3 in brown preadipocytes inhibits insulin signaling, whereas TRB3KO mice displays improved insulin signaling in brown adipose tissue.

- Insulin signaling is required for the effects of TRB3 to regulate brown adipose tissue differentiation and activity. 

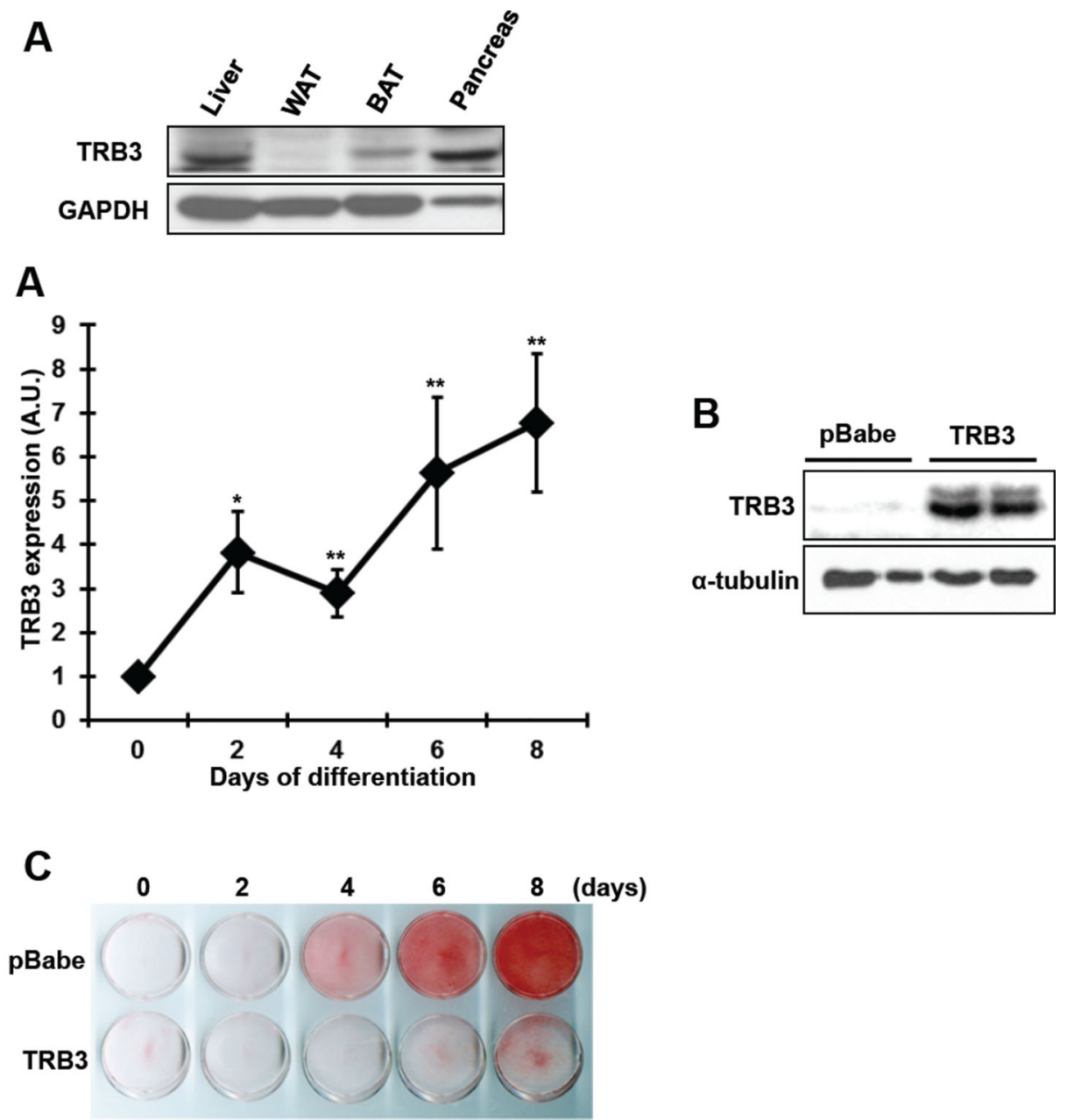

D

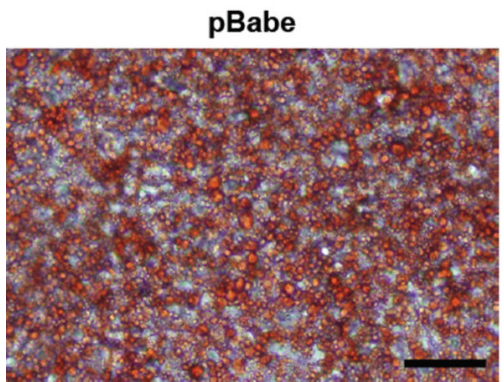

TRB3

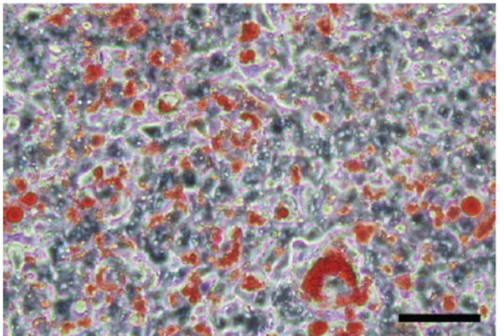

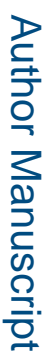


E

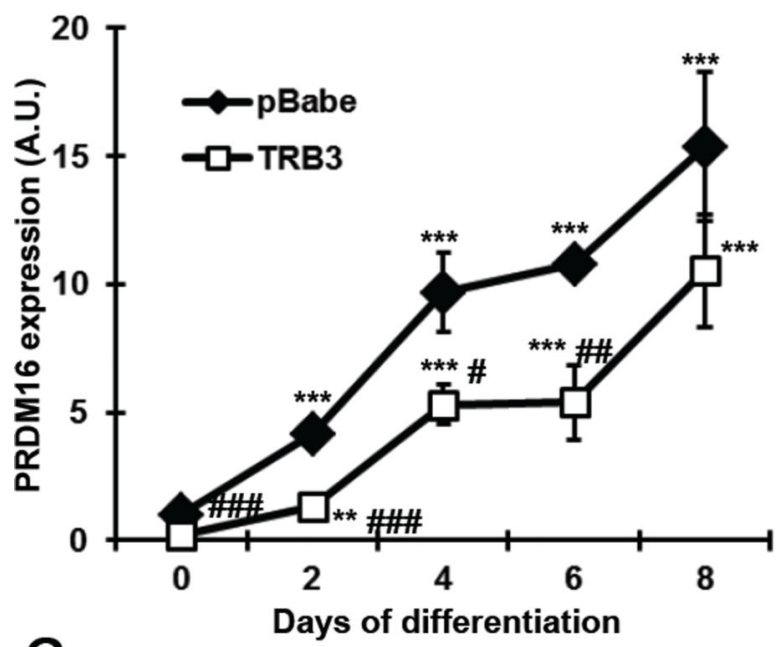

G

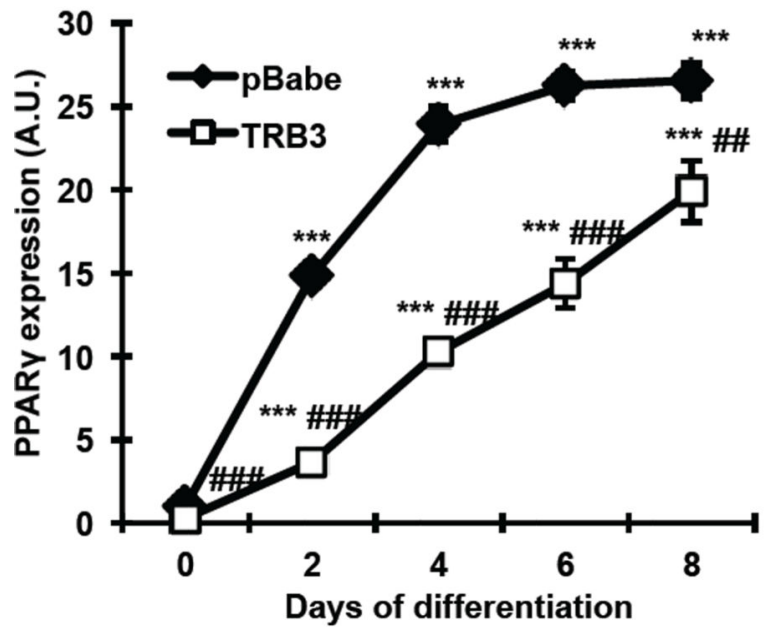

$\mathbf{F}$

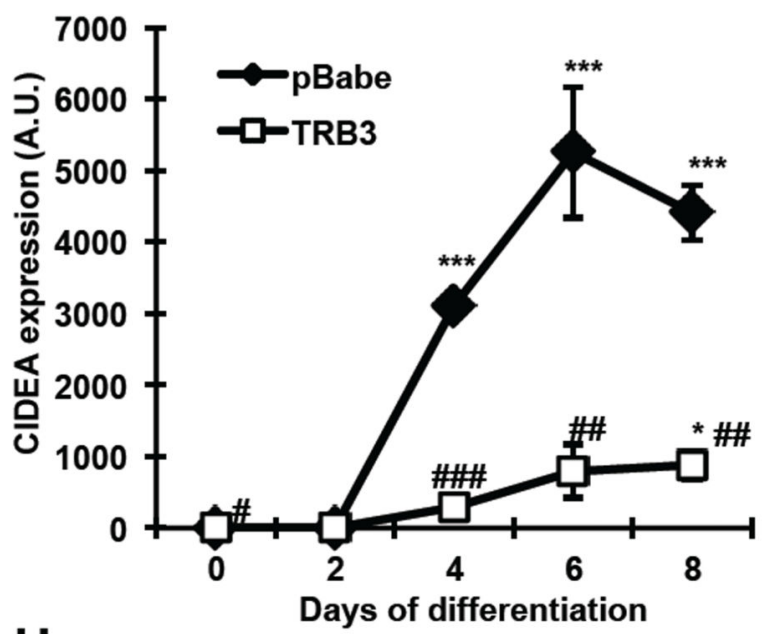

H

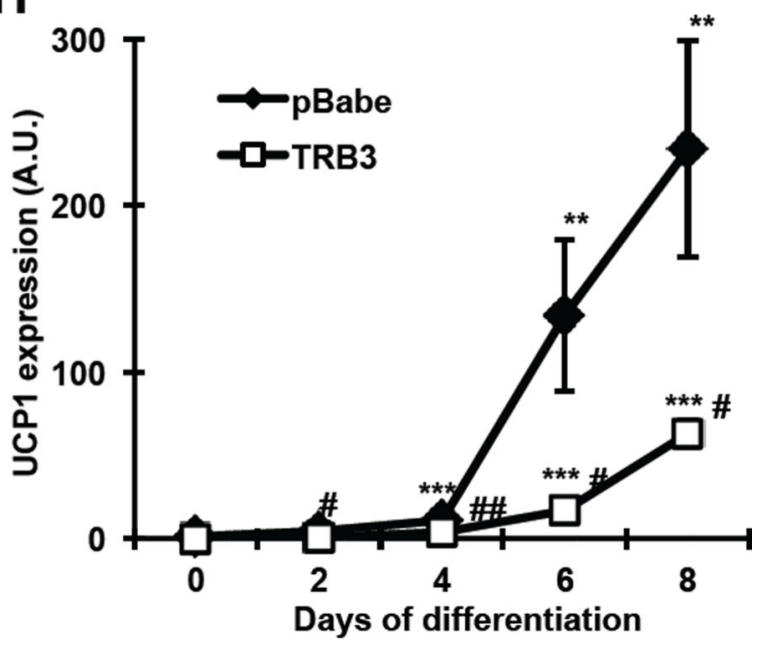

I

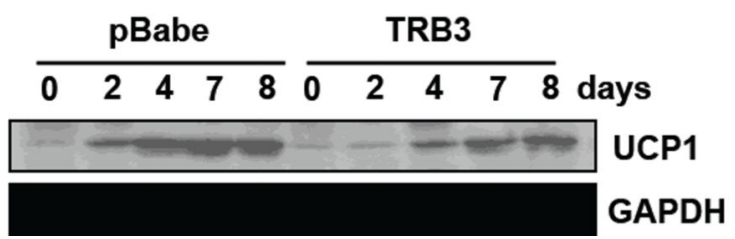

Fig. 1. Effects of TRB3 on brown preadipocyte differentiation

(a) Western blot analysis was performed to determine protein expression of TRB3 in the tissues from 12-week-old male C57BL/6. (b) Brown preadipocytes were differentiated to brown adipose cells for 8 days. Cells were collected at indicated days to determine TRB3 mRNA expression using Real-time PCR analysis ( $n=5)$. (c) Brown preadipocytes were infected with retrovirus containing empty vector (pBabe) or TRB3. Western blot analysis was performed to detect TRB3 expression in the cells. (d-j) Brown preadipocytes had undergone differentiation for 8 days. On day 8 , the cells were fixed and stained with Oil Red 
$\mathrm{O}$ to visualize fat accumulation ( $\mathrm{d}$ and e; Bar $100 \mu \mathrm{m}$ ). RNA was isolated from cells during differentiation to measure mRNA expression of PRDM16 (f), CIEDA (g), PPAR $\gamma(\mathrm{h})$, and UCP1 (i) ( $n=5)$. Protein lysates were subjected to gel electrophoresis to determine the UCP1 expression (j). Data are the means \pm S.E.M. * indicates $\mathrm{p}<0.05$, ** indicates $\mathrm{p}<0.01$, and $* * * *$ indicates $\mathrm{p}<0.001$ vs. basal in the same group. \# indicates $\mathrm{p}<0.05$, \#\# indicates $\mathrm{p}<0.01$, and \#\#\# indicates $\mathrm{p}<0.001$ vs. corresponding control. 
A

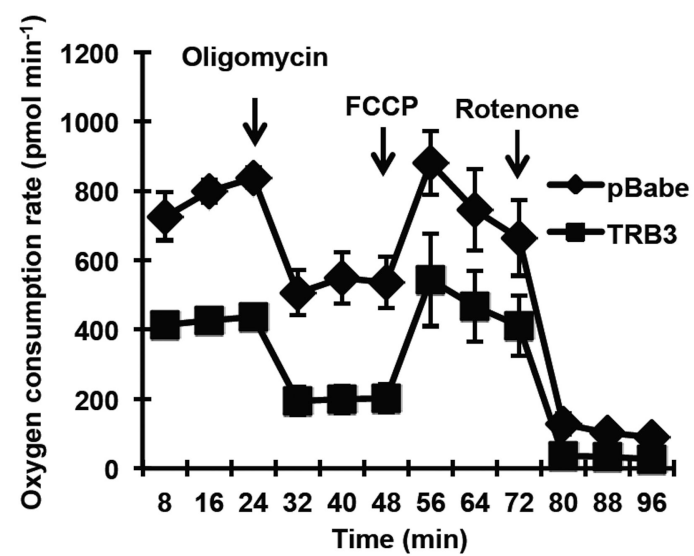

C

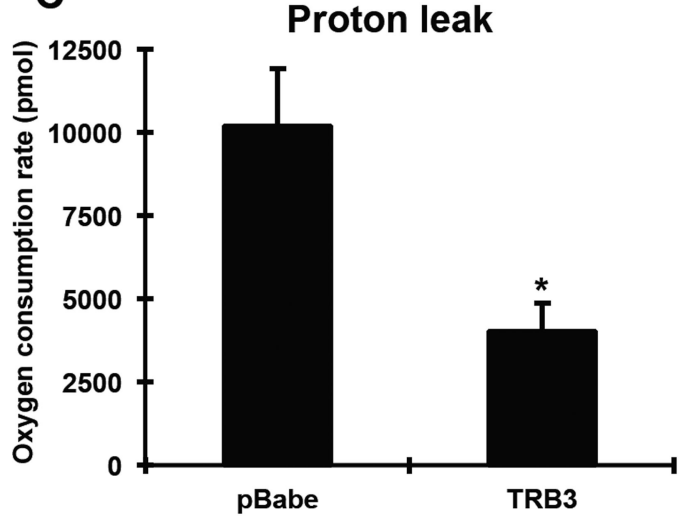

$\mathbf{E}$

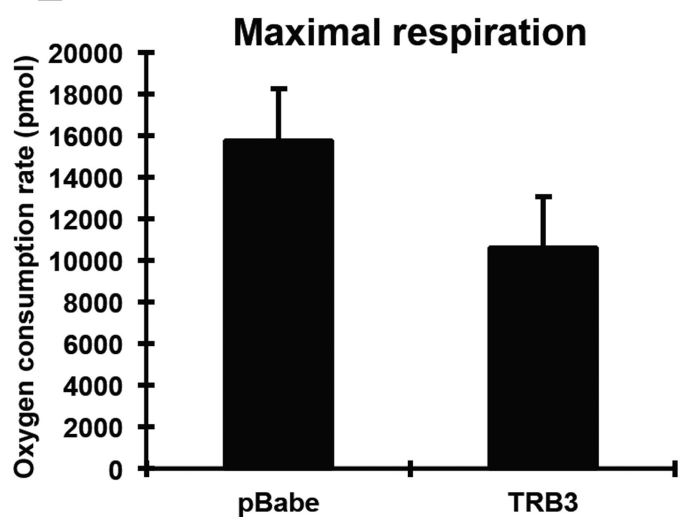

B

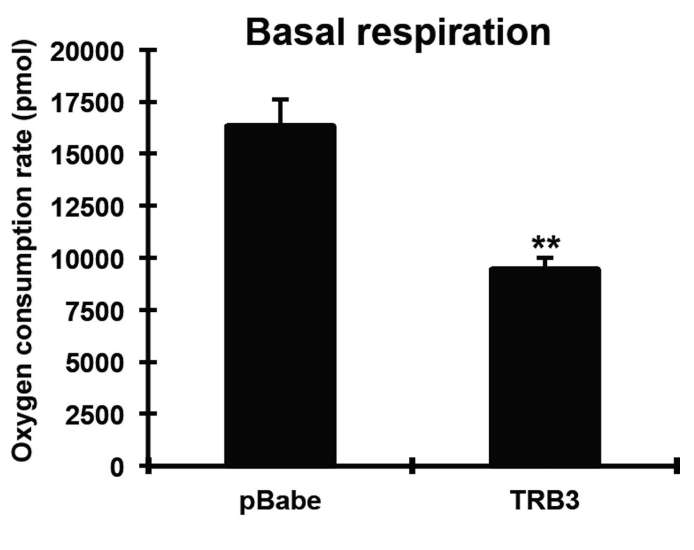

D

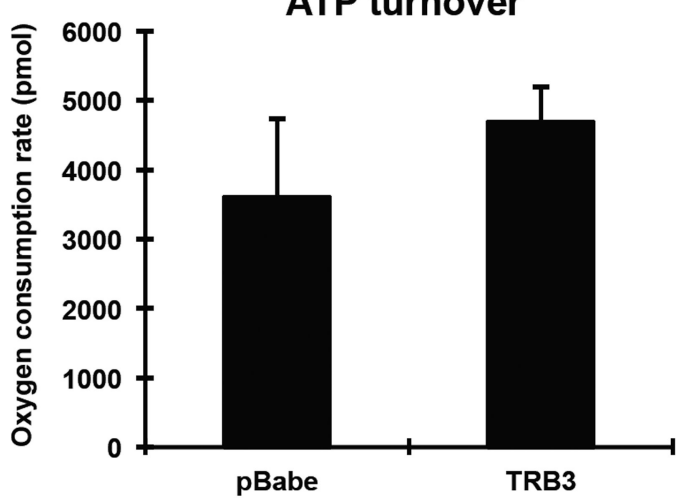

Fig. 2. The effects of TRB3 on cellular bioenergetics in brown adipose cells (a-e) Brown preadipocytes were differentiated for 5 days. The metabolic profile of brown preadipocytes expressing TRB3 was assessed using a Seahorse XF24 extracellular flux analyser as described in Experimental procedures (a). The rates of basal respiration (b), proton leak (c), ATP turnover (d), and maximal respiration (e) were calculated. Data are the means \pm S.E.M. * indicates $\mathrm{p}<0.05$ and $* *$ indicates $\mathrm{p}<0.01$ vs. pBabe control. 


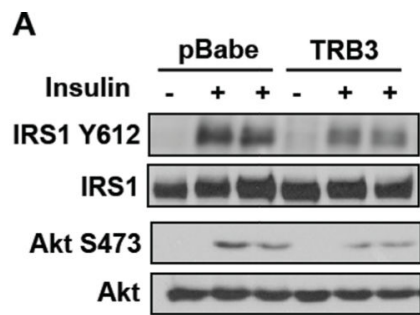

B

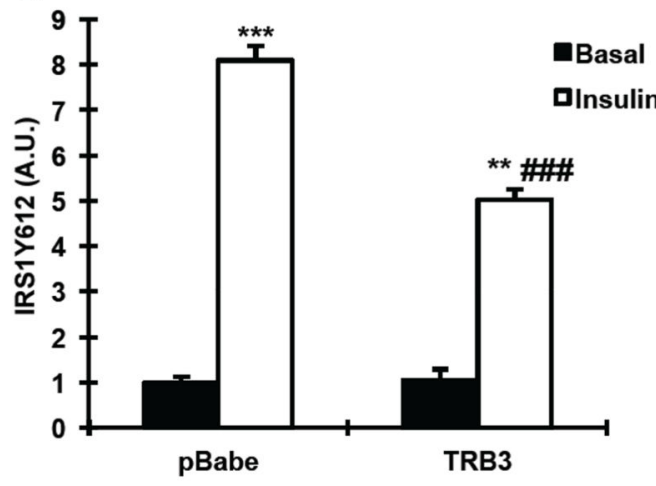

C
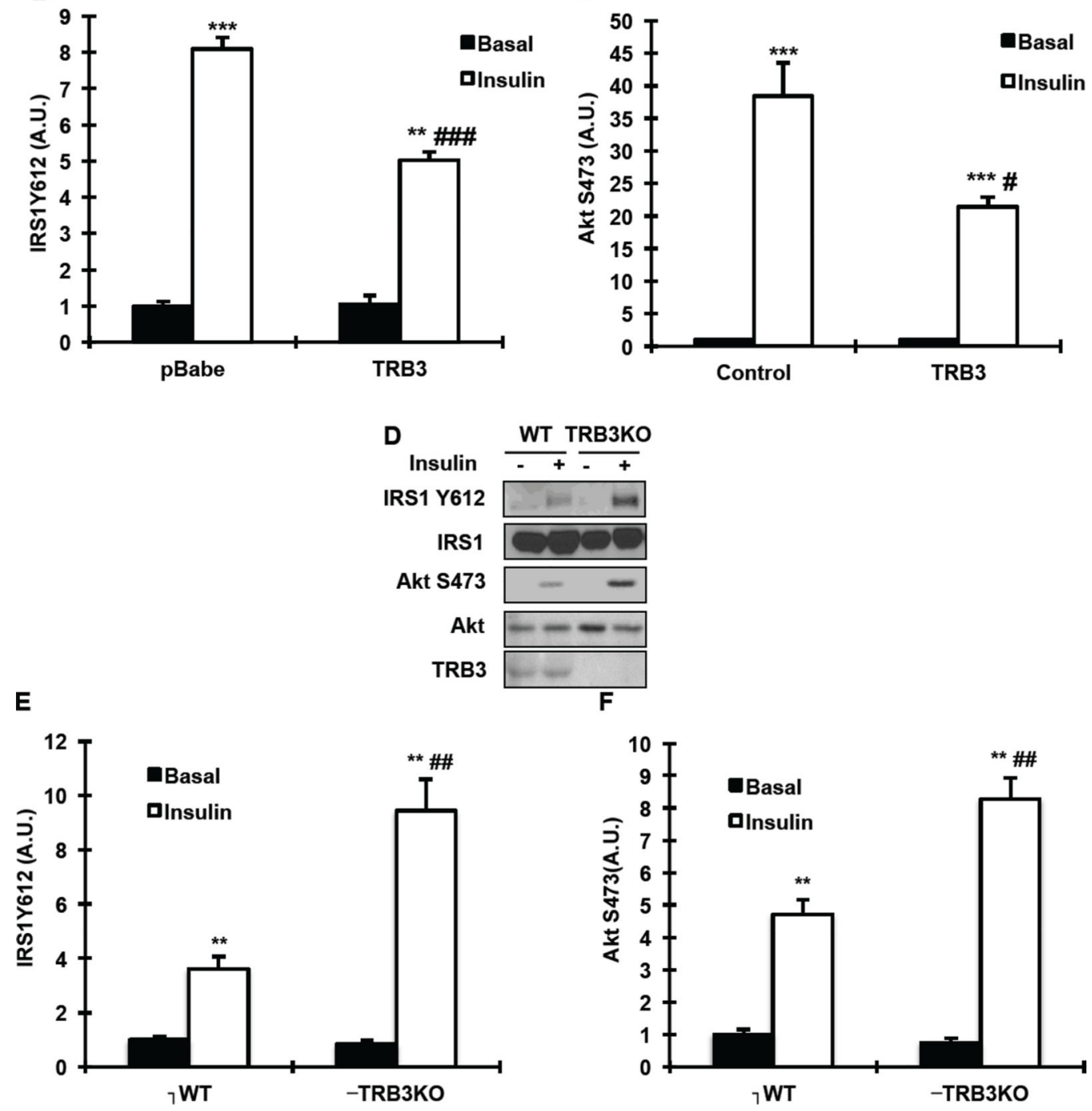

Fig. 3. The effects of TRB3 on insulin signaling in brown preadipocytes and mouse brown adipose tissue

(a-c) Brown preadipocytes were incubated with insulin (100 nM) for 10 min. Cell lysates were subjected to Western blot analysis to determine IRS1 Tyr612 (b) and Akt Ser473 (c). (d-f) Wild type and TRB3KO mice were fasted for 5 hours, injected with saline or insulin (1U/kg) and killed to determine insulin-stimulated phosphorylation of IRS1 at Tyr612 (e) and Akt Ser473 (f) in BAT. Data are the means \pm S.E.M., $n=3-4$ /group. ** indicates $p<0.01$ and $* * *$ indicates $\mathrm{p}<0.001$ vs. wild type or basal in the same group. \# indicates $\mathrm{p}<0.05$, \#\# indicates $\mathrm{p}<0.01$, and \#\#\# indicates $\mathrm{p}<0.001$ vs. corresponding control in the wild type. 
A

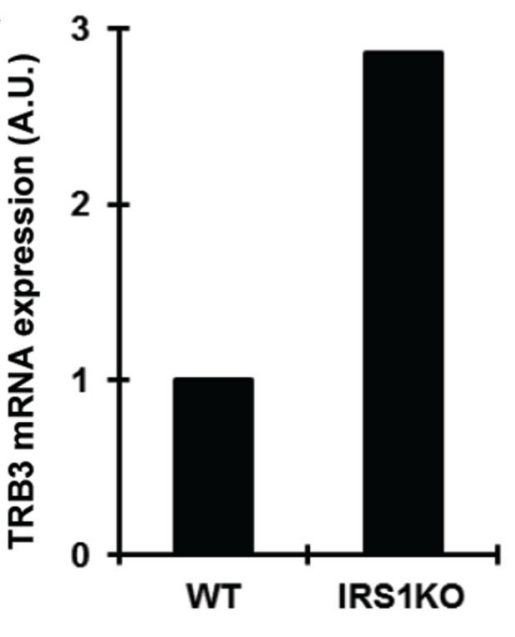

B IRS1KO cells 0 4 6 8 (days)

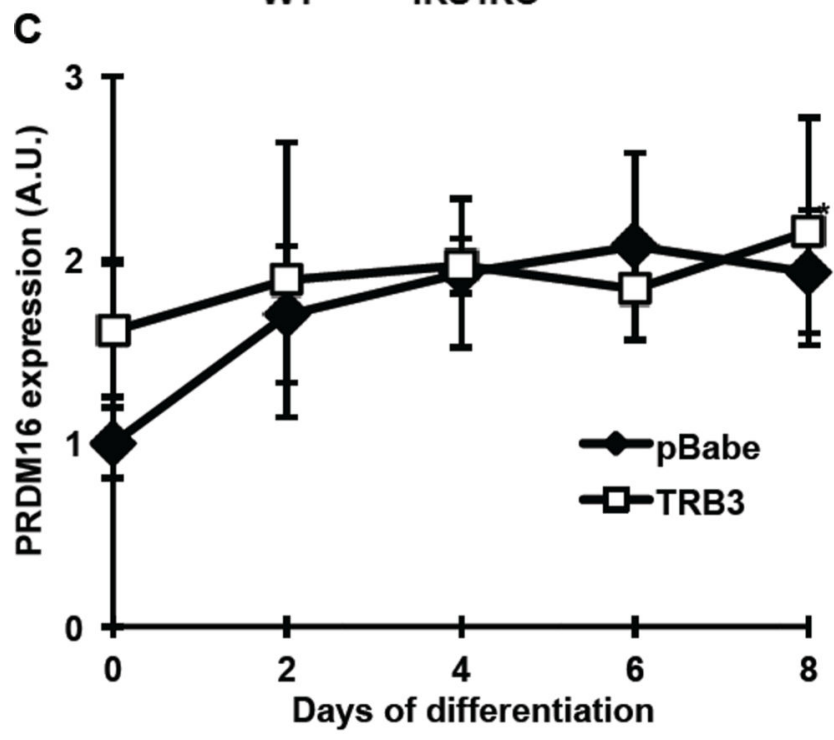

pBabe

TRB3
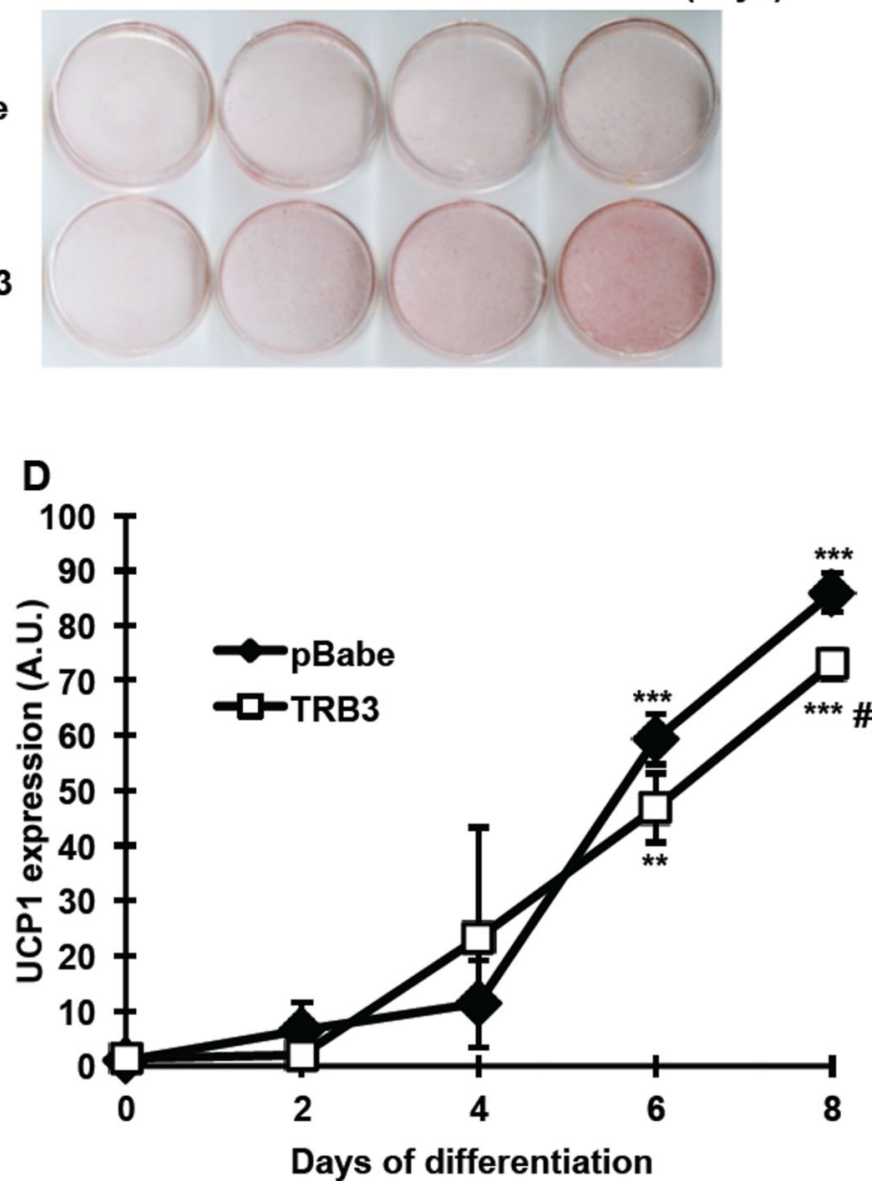

Fig. 4. The effects of TRB3 on brown preadipocytes differentiation in IRS1KO cells (a) RNAs from brown preadipocytes from wild type (WT) or IRS1 knockout mice (IRS1KO) were used to determine TRB3 expression using Real-time PCR analysis ( $n=3)$. (b-d) IRS1KO brown preadipocytes were infected with retrovirus containing empty vector (pBabe) or TRB3. Brown preadipocytes had undergone differentiation for 8 days. Cells were fixed and stained with Oil-Red $\mathrm{O}$ to visualize fat accumulation (b). RNA was isolated from cells during differentiation to measure mRNA expression of PRDM16 (c) and UCP1 (d) $(\mathrm{n}=3)$. Data are the means \pm S.E.M. $* *$ indicates $\mathrm{p}<0.01$ and $* * *$ indicates $\mathrm{p}<0.001 \mathrm{vs.} \mathrm{basal}$ in the same group. \# indicates $p<0.05$ vs. corresponding control in the wild type. 